\title{
First report of Colletotrichum siamense causing anthracnose in Dioscorea cayennensis in Brazil
}

\author{
Francisco Jorge Carlos de Souza Junior $^{1}$ (D) . Mayara Castro Assunção ${ }^{1}$ (D)
}

Received: 16 February 2021 / Accepted: 29 May 2021 / Published online: 5 June 2021

(c) Società Italiana di Patologia Vegetale (S.I.Pa.V.) 2021

Keywords Fungi $\cdot$ Phylogeny $\cdot$ Morphology $\cdot$ Pathogenicity $\cdot$ Yam

Yam (Dioscorea cayennensis) is a crop of importance for the northeastern region of Brazil, being one of the main tubers for supplying domestic trade, in addition to being an important export product (Mesquita 2002). Samples of D. cayennensis leaves with leaf spots that evolved to necrosis, typical symptoms of anthracnose, were collected in August 2019 in Bonito, Pernambuco, Brazil, with an incidence of the disease in 35\% of the total area of 5 ha production. The fungus was isolated from leaf lesions, cultivated on potato dextrose agar (PDA) and incubated at $25 \pm 2{ }^{\circ} \mathrm{C}$. After isolation, 10 pure cultures, by isolation of single spores, morphologically similar were obtained that developed characteristic mycelium. The resulting thalli were circular with grayish white aerial mycelium and with masses of pink conidia. The conidia $(\mathrm{n}=$ 50) were cylindrical, 14.1-19.5 $\times 4.1-5.2 \mu \mathrm{m}$, hyaline, aseptate, with rounded ends. Based on the morphological data, it was identified as Colletotrichum sp. For molecular identification, the region of the internal transcribed spacer (ITS), actin (ACT), glyceraldehyde-3-phosphate dehydrogenase (GAPDH), intergenic region between Apn2 and MAT1-2-1 (ApMAT) and $\beta$-tubulin 2 (TUB2) were used, being analyzed with the method of Weir et al. (2012). The sequences were deposited at GenBank (ITS: MW566604; ACT: MW574140; GAPDH: MW574139; ApMAT: MZ191078; TUB2: MW574138). Phylogenetic analyses were performed using maximum likelihood (ML) method for both individual loci and the concatenated alignment, confirming the strain as Colletotrichum siamense. The pathogenicity of the isolate was confirmed by spraying a suspension of conidia $(1 \times$

Francisco Jorge Carlos de Souza Junior

jorgesouza@alu.ufc.br

1 Estudante de doutorado do Programa de Pós Graduação em Fitopatologia, Departamento de Agronomia, Universidade Federal Rural de Pernambuco, Recife, Pernambuco, Brazil $\left.10^{6} \mathrm{~mL}^{-1}\right)$, from a 7-day culture grown under environmental conditions $\left(25 \pm 2^{\circ} \mathrm{C}\right)$, on the leaves of D. cayennensis, followed by incubation in a humid chamber $\left(25^{\circ} \mathrm{C}\right.$ and humidity $\pm 75 \%$ ). In the control, the leaves were sprayed only with sterile distilled water. One week after inoculation, symptoms were observed only in the inoculated leaves. The fungus was re-isolated, confirming the pathogenicity of $C$. siamense in D. cayennensis. Anthracnose in Dioscorea spp. has been associated with $C$. karstii, C. siamense and $C$. tropicale in Puerto Rico (Aponte et al. 2014), but as far as we know, this is the first report of $C$. siamense that caused anthracnose in Dioscorea cayennensis in Brazil.

Acknowledgements The authors thank the Coordenação de Aperfeiçoamento de Pessoal de Nível Superior - Brasil (CAPES) and the Conselho Nacional de Desenvolvimento Científico e Tecnológico Brasil (CNPq) for funding part of this research.

\section{References}

Aponte SEF, Rivera MF, Vargas LIR, Velez AG (2014) Identification and characterization of Colletotrichum spp. affecting yam (Dioscorea spp.) crop in Puerto Rico. Phytopathology 105(Suppl. 1):S1.2

Mesquita AS (2002) Inhame e taro: cenários dos mercados internacional, brasileiro e baiano. Bahia Agrícola 5(2):54-64

Weir BS, Johnston PR, Damm U (2012) The Colletotrichum gloeosporioides species complex. Stud Mycol 73(3):115-180

Publisher's Note Springer Nature remains neutral with regard to jurisdictional claims in published maps and institutional affiliations. 